\title{
Optimalisasi Website kedirimenjual.com untuk Meningkatkan Brand Awareness Produk UMKM Kabupaten Kediri Melalui Digital Marketing
}

\author{
Setyo Tri Wahyudia*, Sovia Rosalin ${ }^{b}$, M.Daniel Septian ${ }^{b}$, Soni Laksono \\ ${ }^{a}$ Fakultas Ekonomi dan Bisnis Universitas Brawijaya

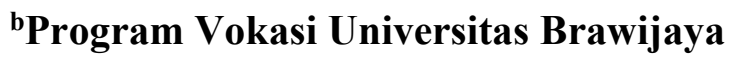 \\ 'Fakultas Ilmu Administrasi Universitas Brawijaya
}

"Korespondensi: setyo.tw@ub.ac.id

\begin{abstract}
ABSTRAK
Digital marketing menjadi kunci untuk mengembangkan dan mengenalkan produk daerah di kancah global. Pemerintah Kabupaten Kediri memfasilitasi pelaku UMKM dalam pemasaran produk melalui website kedirimenjual.com yang dikelola Dinas Perdagangan Kabupaten Kediri. Melalui Kegiatan Program Doktor Mengabdi yang digagas oleh LPPM Universitas Brawijaya, berusaha membantu dalam upaya mengoptimalkan website tersebut. Kegiatan yang dilakukan berupa pembenahan spesifikasi website, peningkatan kualitas pengelola website, dan penyediaan database UMKM. Desain kegiatan ini dilakukan melalui tahapan analisis komparasi website kedirimenjual.com dengan kompetitor sejenis, analisis kebutuhan content/muatan website kedirimenjual.com, merancang dan membangun sistem aplikasi website kedirimenjual.com, uji coba website kedirimenjual.com, dan pemeliharaan website dengan update content dan informasi produk UMKM di Kabupaten Kediri. Optimalisasi spesifikasi website dilakukan dengan meredesain website sebelumnya supaya lebih dinamis dan interaktif dengan menambahkan beberapa fitur tambahan. Kemudian, peningkatan kemampuan pengelola website dilakukan dengan pelaksanaan Training of Trainers bagi pengelola Admin di Dinas Perdagangan. Berdasarkan evaluasi dan monitoring oleh Pemerintah Kabupaten Kediri, kegiatan optimalisasi website kedirimenjual.com telah memberikan dampak signifikan bagi pengembangan dan promosi UMKM di wilayah Kabupaten Kediri dan luar daerah. Kedepannya, untuk menjaga keberlanjutan bagi pelaku UMKM dalam berproduksi serta memasarkan melalui platform website, Pemerintah Kabupaten Kediri perlu menyiapkan strategi yang terukur untuk menjaga keberlanjutan website tersebut.
\end{abstract}

Kata Kunci: Kedirimenjual.com, UMKM, Brand Awareness, Digital Marketing

\begin{abstract}
Digital marketing is the key to developing and introducing regional products on the global scene. The Government of Kediri Regency facilitates SMEs in marketing products through the website kedirimenjual.com which is managed by the Kediri Regency Trade Office. Through the Service of the Serving Doctoral Program, which was initiated by LPPM Universitas Brawijaya, trying to help in the effort to optimize the website. The activities carried out in the form of revamping the website specifications, improving the quality of website managers, and providing the SMEs database. The design of this activity is carried out through the comparative analysis stages of the website kedirimenjual.com with similar competitors, analysis of the content/content needs of the website kedirimenjual.com, designing and building a system application website kedirimenjual.com, testing the website kedirimenjual.com,
\end{abstract}


Jurnal Pengabdian dan Pengembangan Masyarakat,

Vol.2 No. 2, November 2019, 1-7

and maintaining the website with content updates and SMEs product information in Kediri Regency. Optimizing website specifications is done by redesigning the previous website to make it more dynamic and interactive by adding some additional features. Then, improving the ability of website managers is done by implementing Training of Trainers for Admin administrators at the Trade Office. Based on evaluation and monitoring by the District Government of Kediri, the optimization of the kedirimenjual.com website has had a significant impact on the development and promotion of SMEs in the Kediri Regency and outside the region. In the future, to maintain sustainability for SMEs in producing and marketing through a website platform, the local government of Kediri needs to prepare a measurable strategy to maintain the sustainability of the website.

Keywords: Kedirimenjual.com, SMEs, Brand Awareness, Digital Marketing

\section{PENDAHULUAN}

Kabupaten Kediri sebagai satu dari 38 kabupaten/kota di Propinsi Jawa Timur memiliki potensi ekonomi yang besar dalam mendorong perekonomian daerah, juga Jawa Timur. Salah satu potensi tersebut ditunjukkan oleh banyaknya pelaku usaha kecil di Kabupaten Kediri. Menurut data BPS, jumlah usaha kecil di Kabupaten Kediri mencapai 1.238 usaha kecil (pada 2016) serta dengan jumlah rumah tangga mencapai $524.358 \mathrm{kk}$, menjadikan sektor usaha kecil memiliki peranan penting dalam ekonomi Kabupaten Kediri. Peranan tersebut setidaknya dapat ditunjukkan oleh kontribusinya dalam pertumbuhan ekonomi daerah serta pengurangan kemiskinan. Sektor pertanian merupakan salah satu penopang berkembangnya usaha kecil di Kabupaten Kediri. Sektor ini terkait dengan posisi Kabupaten Kediri yang merupakan daerah pertanian dan perkebunan yang subur serta didukung oleh subsektor peternakan dan perikanan.

Tabel 1. Deskripsi Kabupaten Kediri

\begin{tabular}{|c|c|c|c|}
\hline \multirow{2}{*}{ Keterangan } & \multicolumn{3}{|c|}{ Tahun } \\
\hline & 2014 & 2015 & 2016 \\
\hline Jumlah Penduduk & 1.492 .585 & 1.544 .639 & 1.566 .589 \\
\hline Jumlah Rumah Tangga & 467.274 & 522.317 & 524.358 \\
\hline Jumlah Usaha Kecil & 1.178 & 1.074 & 1.238 \\
\hline Jumlah Usaha Menengah & 48 & 76 & 54 \\
\hline Jumlah Usaha Besar & 11 & 5 & 9 \\
\hline Jumlah Pencari Kerja & 10.706 & 10.523 & 10.312 \\
\hline Jumlah Lowongan Kerja & 10.287 & 10.023 & 10.004 \\
\hline
\end{tabular}

Sumber: Kediri Dalam Angka 2018

Berbagai langkah strategis untuk meningkatkan dan mengembangkan potensi pertanian di Kabupaten Kediri terus diupayakan. Pada tahun 2015, Bupati Kediri bersama-sama dengan jajaran keamanan melakukan kerjasama dalam rangka pengamanan distribusi pupuk, perbaikan irigasi, pengadaan bibit, proses tanam dan panen hingga pemasaran sinergis dengan Tim Ketahanan Pangan Pemerintah Kabupaten Kediri. Hasilnya, PDRB Kabupaten Kediri meningkat (33 triliun Rupiah pada 2016) diikuti dengan pendapatan perkapita Kabupaten Kediri mengalami peningkatan $(21,36$ juta/tahun pada 2016) seiring dengan berkembangnya sektor pertanian. 
Tabel 2. PDRB Atas Dasar Harga Berlaku (ADHB) dan Atas Dasar Harga Konstan (ADHK)

Kabupaten Kediri (Jutaan Rupiah)

\begin{tabular}{lrrr}
\hline \multicolumn{1}{c}{ PDRB } & 2014 (Rp) & 2015 (Rp) & \multicolumn{1}{c}{ 2016 (Rp) } \\
\hline ADHB & 27,751 Triliun & 30,493 Triliun & 33,201 Triliun \\
ADHK & 22,886 Triliun & 24,004 Triliun & 25,208 Triliun \\
Pertumbuhan Ekonomi & $5,32 \%$ & $4,88 \%$ & $5,02 \%$ \\
Kemiskinan & 196.780 jiwa & 199.380 jiwa & 197.430 jiwa \\
Pendapatan Per Kapita & 18,04 juta/tahun & 19,72 juta/tahun & 21,36 juta/tahun \\
\hline
\end{tabular}

Sumber: Kediri Dalam Angka 2018

Upaya lainnya dalam meningkatkan perekonomian Kabupaten Kediri juga dilakukan melalui reformasi birokrasi. Komitmen tersebut tertuang dalam Dokumen Roadmap Reformasi Birokrasi Kabupaten Kediri Tahun 20152020 sesuai amanah Peraturan Menteri Pendayagunaan Aparatur Negara dan Reformasi Birokrasi Nomor 37 Tahun 2013 tentang Pedoman Penyusunan Roadmap Reformasi Birokrasi. Untuk menjamin terlaksananya reformasi birokrasi tersebut, maka Pemerintah Kabupaten Kediri mengeluarkan Keputusan Bupati Kediri Nomor 188.45/498/418.32/2015 tentang penetapan tim pengarah dan tim pelaksana reformasi birokrasi Kabupaten Kediri. Melalui pelaksanaan reformasi birokrasi, Pemerintah Kabupaten Kediri meyakini bahwa berbagai strategi untuk meningkatkan perekonomian daerah dapat berjalan lebih baik dan efisien.

Di Kabupaten Kediri, kegiatan reformasi birokrasi sudah dilakukan sejak tahun 2010 melalui pengembangan berbagai aplikasi sistem manajemen keuangan dan pelayanan publik. Pengembangan aplikasi sistem tersebut bertujuan untuk meningkatkan penyelenggaraan tata kelola pemerintahan yang bersih dan bebas korupsi, meningkatkan pelayanan publik kepada masyarakat, dan meningkatkan akuntabilitas kinerja instansi Pemerintah. Aplikasi sistem terdiri dari sistem perencanaan, penatausahaan keuangan sampai dengan sistem aplikasi untuk pelaksanaan pengawasan keuangan oleh inspektorat, serta aplikasi sistem online dalam pelayanan publik khususnya perijinan. Khusus untuk aplikasi perijinan, telah dilakukan melalui penerbitan Peraturan Daerah Kabupaten Kediri tentang Perijinan Satu Pintu. Kedepan, melalui reformasi birokrasi, Pemerintah Kabupaten Kediri akan melakukan pelayanan publik secara online sehingga mampu meningkatkan kualitas dan kecepatan pelayanan masyarakat yang terserah secara luas di 26 kecamatan Kabupaten Kediri.

Tabel 3. Aplikasi Sistem Informasi di Kabupaten Kediri

\begin{tabular}{rlc}
\hline No & \multicolumn{1}{c}{ Nama Aplikasi Sistem } & Tahun \\
\hline 1. & Pengembangan website (portal) Pemerintah Daerah & 2009 \\
2. & Sistem Informasi Manajemen Keuangan Daerah (SIMDA) & 2010 \\
3. & Sistem Informasi Manajemen Aset Daerah & 2010 \\
4. & Sistem Pengadaan Barang \& Jasa Secara Elektronik (SPSE) & 2011 \\
5. & Sistem Informasi Perencanaan Pembangunan (SIPP) & 2012 \\
6. & Sistem Informasi Jasa Konstruksi (SIPJAKI) & 2012 \\
7. & Sistem Jaringan Dokumentasi dan Informasi Hukum (JDIH) & 2012 \\
8. & Sistem Informasi Manajemen Kepegawaian & 2013 \\
\hline
\end{tabular}

Sumber: Dokumen Roadmap Reformasi Birokrasi Kabupaten Kediri, 2019. 
Dalam upaya menuju tata kelola electronic government (e-gov), Pemerintah Kabupaten Kediri sebagaimana sudah tertuang dalam dokumen roadmap reformasi birokrasi, bertekad terus mengembangkan berbagai aplikasi sistem untuk mendukung kemudahan penyelenggaraan pemerintahan dan peningkatan kualitas pelayanan. Aplikasi sistem tersebut antara lain aplikasi computer assesment test (CAT) dalam proses seleksi CPNS, sistem presensi online, sistem manajemen arsip elektronik (digital), sistem informasi tunjangan perbaikan penghasilan, dan berbagai aplikasi sistem informasi lainnya.

Di bidang pengembangan dan pemasaran produk unggulan daerah, Pemerintah Kabupaten Kediri telah memiliki platform aplikasi untuk meningkatkan penjualan produk-produk unggulan daerah secara daring. Platform tersebut berupa website kedirimenjual.com yang dikelola oleh Organisasi Perangkat Daerah (OPD) Dinas Perdagangan Kabupaten Kediri. Namun demikian, dalam perjalanannya, website tersebut dirasa masih belum mampu memberikan manfaat yang besar bagi pengembangan dan penjualan produk unggulan daerah. Hingga 2019, pemanfaatan website dirasakan masih belum dimanfaatkan secara luas, terlihat dari produk yang didaftarkan masih minim. Selain fitur dan desain website yang masih kurang maksimal, produk UKM yang ditampilkan juga kurang informatif. Oleh karena itu, perlu adanya perbaikan fitur dan desain website serta perbaikan sentuhan akhir produk sehingga produk yang ditampilkan menarik.

Perkembangan teknologi digital yang masih diyakini memberi peluang bagi para pelaku UKM untuk memasarkan produknya dan melakukan transaksi secara online (Wardhana, 2015). Berdasarkan hasil survey Asosiasi Penyelenggara Jasa Internet Indonesia tahun 2018 (APJII, 2019) menunjukkan bahwa sebanyak 171 juta jiwa penduduk
Indonesia (dari total sebanyak 264 juta penduduk) menggunakan internet. Angka itu berarti sekitar 64 persen penduduk Indonesia merupakan pengguna internet. Kondisi ini semakin menguatkan tekad untuk mengoptimalkan peran website kedirimenjual.com sebagai platform terdepan dalam memasarkan produk unggulan Kabupaten Kediri.

Pada 2018, Pemerintah Kabupaten Kediri menggandeng Universitas Brawijaya untuk bersama-sama membangun sistem aplikasi yang mampu memberikan manfaat bagi pelaku UMKM di Kabupaten Kediri melalui optimalisasi peran website kedirimenjual.com. Tujuan dari kegiatan ini adalah untuk mengoptimalkan peran website kedirimenjual.com sebagai strategi pemasaran digital pada UKM Kabupaten Kediri. Strategi pemasaran digital dalam bentuk penggunaan website kedirimenjual.com bagi Usaha Kecil dan Menengah (UKM) sangatlah penting, karena dapat memberi pengetahuan kepada para pelaku UKM mengenai cara maupun tahapan dalam memperluas jaringan konsumen melalui pemanfaatan website dalam memasarkan produknya sehingga dapat meningkatkan keunggulan bersaing bagi UKM itu sendiri.

\section{METODE}

Kegiatan ini dilakukan bekerjasama dengan Dinas Perdagangan Kabupaten Kediri sebagai pengelola website kedirimenjual.com. Berdasarkan identifikasi, permasalahan yang dihadapi oleh Dinas Perdagangan adalah sulitnya mengembangkan website kedirimenjual.com sehingga mampu berkontribusi pada pelaku UMKM dan dikenalnya produk-produk unggulan UMKM Kabupaten Kediri. Metode yang digunakan dalam pemecahan permasalahan tersebut adalah sebagai berikut:

i. melakukan analisis komparasi website kedirimenjual.com dengan kompetitor sejenis, 
Setyo Tri Wahyudi, Sovia Rosalin, M.Daniel Septian, Soni Laksono - Optimalisasi Website kedirimenjual.com untuk Meningkatkan Brand Awareness Produk UMKM Kabupaten Kediri Melalui Digital Marketing
ii. analisis
content/muatan
kebutuhan
website
kedirimenjual.com,
$\begin{array}{llr}\text { iii. merancang dan membangun } & \text { mebsite } \\ \text { sistem aplikasi } & \text { wem } \\ \text { kedirimenjual.com, } & \end{array}$
iv. uji coba website
kedirimenjual.com, dan
v. pemeliharaan website dengan
update content dan informasi
produk UMKM di Kabupaten
Kediri.

\section{HASIL DAN PEMBAHASAN}

Digital marketing dapat didefinisikan sebagai kegiatan marketing termasuk branding yang menggunakan berbagai media berbasis web (Wardhana, 2015). Semakin pesatnya perkembangan dan penggunaan teknologi, telah mengubah cara manusia dalam melakukan berbagai aktivitas, termasuk kegiatan transaksi. Bagi konsumen, aktivitas transaksi menggunakan teknologi telah banyak memberikan manfaat, khususnya hemat waktu, biaya dan lebih efisien. Sementara bagi produsen, penggunaan teknologi memberikan keuntungan dalam proses pemasaran produk dengan jangkauan yang lebih luas. Sifat media sosial yang terbuka kemudian dimanfaatkan oleh pelaku usaha khususnya usaha kecil dan menengah (UKM) untuk memasarkan produknya (Wardhana, 2015). Supaya dapat memenangkan persaingan merebut konsumen, para produsen memanfaatkan penggunaan website sebagai strategi memenangkan persaingan melalui pencarian search engine yang mampu menampilkan hasil pencarian produk di halaman paling awal (Anggraeni, 2008).

Usaha Mikro, Kecil, dan Menengah (UMKM) merupakan salah satu bidang yang memberikan kontribusi yang signifikan dalam memacu pertumbuhan ekonomi Indonesia (Jauhari, 2010), khususnya di Kabupaten Kediri. Menurut data BPS, Kabupaten Kediri memiliki jumlah pelaku usaha kecil yang cukup banyak serta memiliki berbagai jenis usaha yang beragam. Berdasarkan pengamatan di lapangan, para pelaku usaha tersebut masih mengandalkan sistem pemasaran yang bersifat konvensional yakni pemasaran produk melalui media toko, pasar, serta aktivitas riil lainnya. Konsekuensinya, pemasaran produk tidak dapat menjangkau wilayah yang luas, serta produk yang dihasilkan belum banyak dikenal oleh masyarakat diluar Kabupaten Kediri. Oleh karena itu, Dinas Perdagangan mencoba membantu mennyelesaikan permasalahan pemasaran produk yang terbatas melalui pengoptimalan website kedirimenjual.com yang selama ini telah ada namun masih belum memberikan banyak manfaat.

Berdasarkan identifikasi dan evaluasi yang dilakukan bersama dengan pengelola website kedirimenjual.com, diketahui terdapat berbagai permasalahan terkait keberadaan website kedirimenjual.com dijabarkan sebagai berikut:

\section{- Komparasi Tampilan}

Salah satu upaya dalam melakukan optimalisasi keberadaan website kedirimenjual.com adalah melakukan komparasi terhadap website sejenis sehingga diketahui kelemahan yang dimiliki. Secara umum website berfungsi sebagai layanan informasi dan memiliki beberapa fungsi spesifik lainnya. Website yang ideal seharusnya memiliki tampilan yang terlihat menarik dan sesuai dengan fungsi atau tujuan awal website tersebut dibentuk. Tampilan website adalah salah satu aspek penting untuk dapat menarik visitor (pengunjung) website tersebut. Selain tampilan website, terdapat fitur-fitur yang beragam dan dapat berjalan dengan sempurna. Tujuan website kedirimenjual.com adalah sebagai wadah para UMKM untuk dapat berjualan secara online. Dalam istilah lain, kedirimenjual.com dibentuk sebagai suatu sistem marketplace yang khusus untuk para wirausahawan di Kabupaten Kediri untuk menambah luas jaringan produk tersebut dapat dijual. 


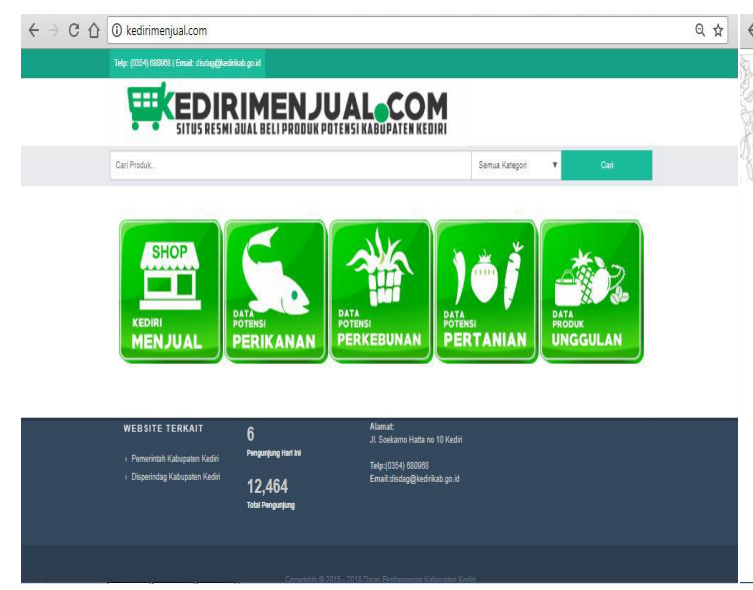

(i) website kedirimenjual.com

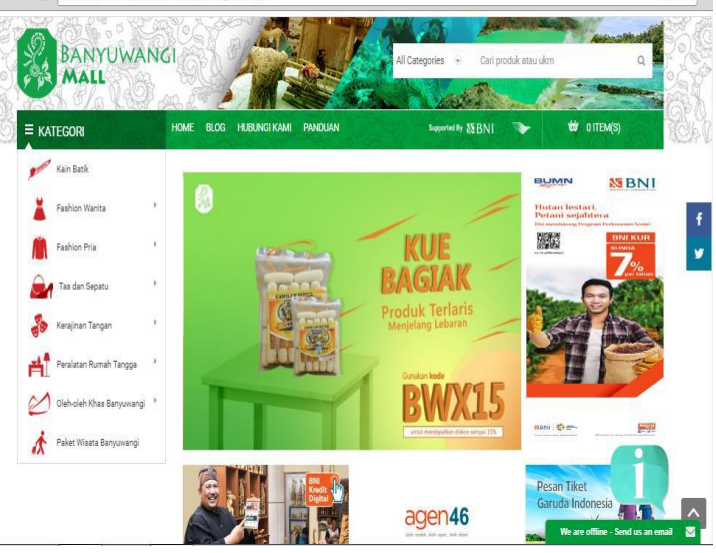

(ii) website banyuwangi-mall.com

Gambar 1. Komparasi Tampilan

Berdasarkan gambar 1 menunjukkan tampilan awal website kedirimenjual.com dengan website banyuwangi-mall.com. berdasarkan gambar 1 tersebut, jika dibandingkan dengan website banyuwangi-mall.com, terdapat beberapa evaluasi dan analisa terkait tampilan awal website kedirimenjual.com yakni tampilan website kedirimenjual.com terlihat kurang menarik dengan desain grafik yang sederhana. Warna hijau pada kategori website tidak mempunyai esensi yang jelas. Tampilan awal hanya berisi konten header-footer dan pilihan kategori. Bagian header website hanya berisi kontak admin dan kolom pencarian, sedangkan bagian footer berisi tentang jumlah visitor (pengunjung) yang tidak biasa dijumpai untuk website marketplace. Pada konten "Kategori", warna yang dipilih tidak senada dengan warna hijau pada header. Desain ikonikon pada setiap kategori juga tidak menarik untuk dilihat.

Jika dibandingkan dengan marketplace yang dibangun oleh Pemerintah Kabupaten Banyuwangi berupa website banyuwangi-mall.com terdapat perbedaan yang signifikan. Tampilan website banyuwangi-mall.com lebih menarik dibandingkan website kedirimenjual.com. Pada website banyuwangi-mall.com terdapat fitur-fitur yang beragam. Desain website banyuwangi-mall.com memiliki pilihan warna hijau yang senada dengan desain konten lainnya. Fitur "Kategori" pada tampilan website juga terlihat menarik dengan pilihan ikon berwarna merah. Ikon-ikon setiap kategori juga mewakilkan setiap sub-kategori dengan desain yang menarik. Kemudian, desain header website terlihat menarik pula dengan mencantumkan desain batik yang sederhana, namun indah untuk dipandang. Terdapat fitur menu yang beragam, yaitu Home, Blog, Hubungi Kami, Panduan, kolom pencarian, keranjang belanja, hingga ikon facebook dan twitter untuk dapat langsung menghubungkan pengunjung ke media sosial. Selain itu terdapat fitur percakapan langsung dengan admin untuk bagi pelanggan untuk menanyakan sesuatu yang tidak pelanggan mengerti.

Tampilan website banyuwangimall.com lebih mencerminkan suatu marketplace pada umumnya. Tampilan website menyuguhkan produk-produk highlight yang terdapat pada kategori yang disediakan. Pengunjung dapat lebih mudah mencari produk yang diinginkan dengan adanya fitur subkategor juga terdapat kategori yang diberi konten keterangan harga yang dapat menarik pelanggan untuk berbelanja. Terdapat label harga dan judul atau nama produk yang dibuat berbeda seakan mempertegas harga yang dijual, membuat penglihatan pelanggan dapat teralihkan.

- Komparasi Fitur Kategori Website 
Fitur dalam website memiliki peran penting dalam menarik minat pengunjung untuk terus berselancar dalam website. Oleh karena itu, website perlu memiliki

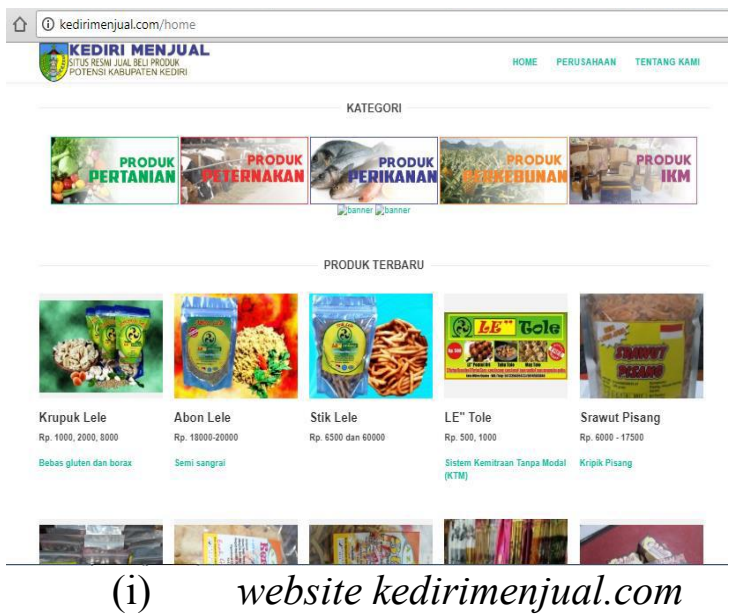

fitur-fitur yang menarik dan membuat pengunjung betah membaca content dalam fitur yang disediakan.

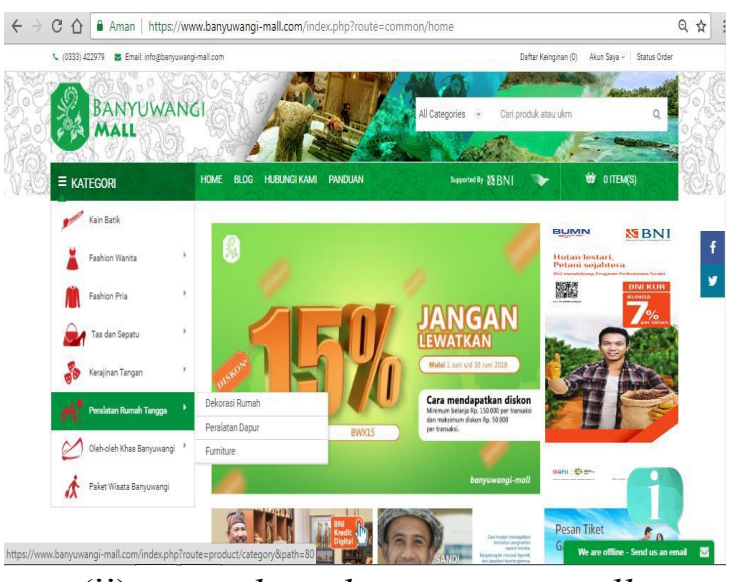

(ii) website banyuwangi-mall.com

Gambar 2. Komparasi Tampilan Kategori

Berdasarkan gambar 2 menunjukkan tampilan kategori pada website kedirimenjual.com masih sederhana dan kurang menarik. Namanama kategori dalam website kedirimenjual.com belum spesifik dibandingkan website banyuwangi-mall. Bentuk desain kategori dalam website kedirimenjual.com sangat sederhana serta memiliki gambar yang kurang menarik. Sebaliknya, pada website banyuwangimall, kategori dipisahkan menjadi beragam kategori lengkap dengan subkategori. Hal tersebut dapat memudahkan pengunjung untuk mencari produk yang diinginkan. Ikon kategori yang berwarna merah dapat meningkatkan pusat

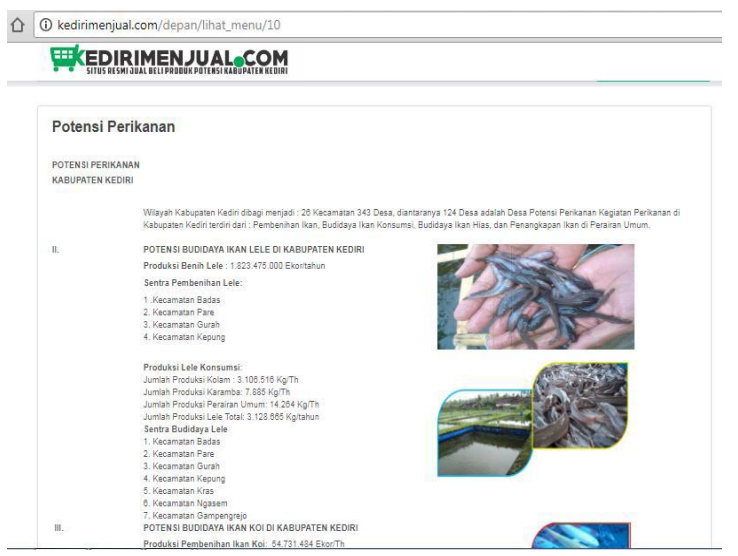

(i) website kedirimenjual.com perhatian yang lebih pada pengunjung. Ikon dibuat menarik sesuai dengan nama kategori.

\section{- Komparasi Fitur Blog pada Website}

Selain fitur kategori yang harus beragam dan menampilkan berbagai hal terkait tujuan dari website, fitur lain yang juga tidak kalah penting adalah fitur $b l o g$. Fitur blog merupakan fitur yang dibuat dalam sebuah website yang disesuaikan dengan tujuan dibuatnya website. Jika website tersebut untuk mengenalkan produk unggulan dan memasarkannya, maka fitur blog dibuat dengan menambahkan tautan gambar ataupun link berkaitan dengan tujuan website.

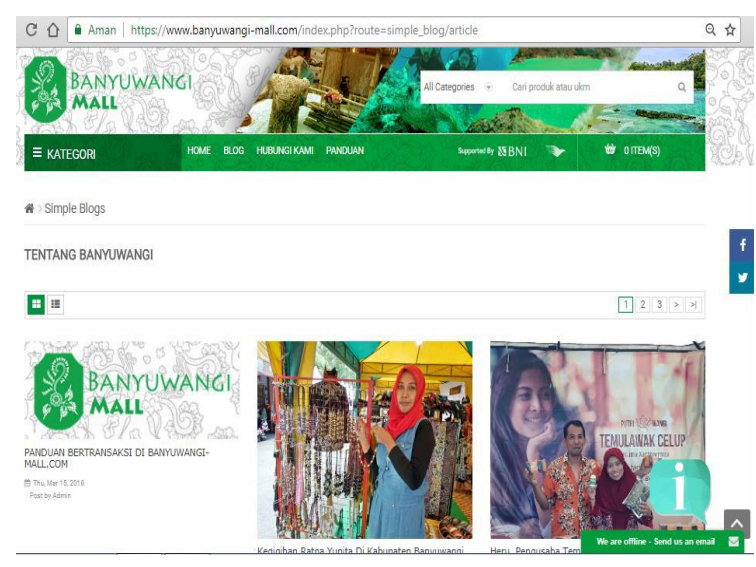

(ii) website banyuwangi-mall.com Gambar 3. Komparasi Tampilan Fitur 
Berdasarkan gambar 3, fitur data pada website kedirimenjual.com terkesan kurang menarik, bahkan seperti blog yang cocok untuk suatu blog artikel.
Selain itu, gambar yang ditampilkan dalam website kedirimenjual.com juga tidak menarik untuk dilihat dan dibaca.

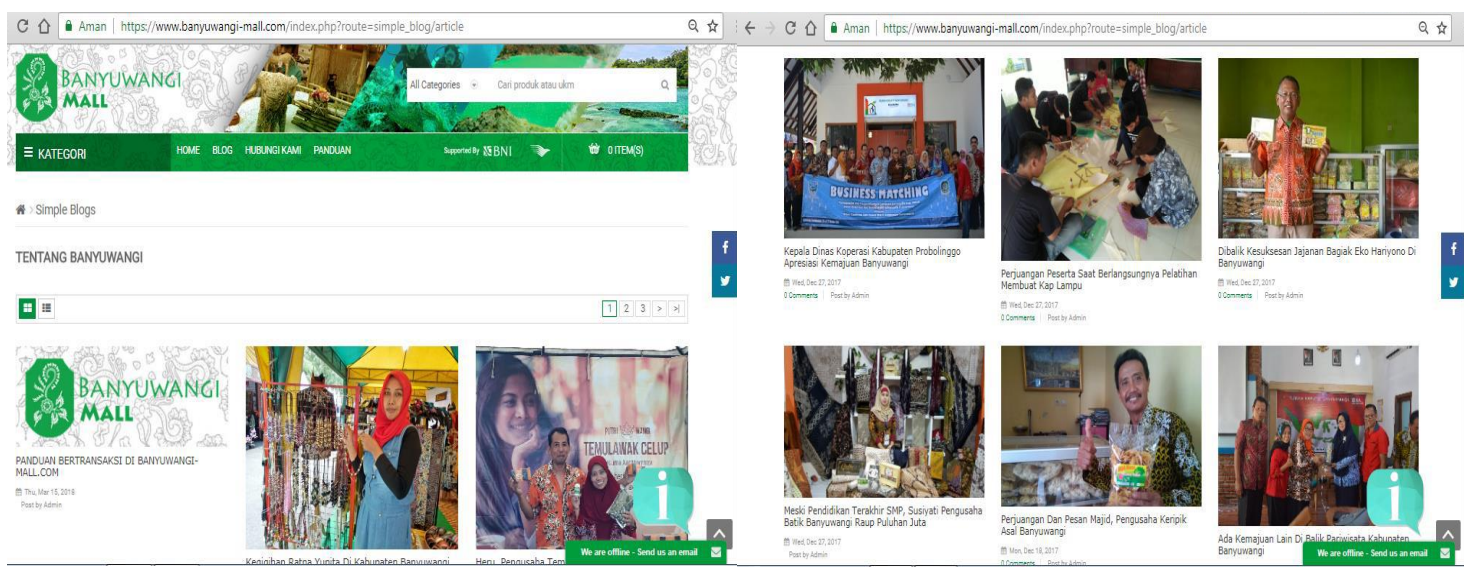

Gambar 4. Tampilan Fitur Blog Website Banyuwangi-mall.com

Pada website banyuwangimall.com, fitur blog yang ditampilkan menggunakan gambar yang relevan dengan tujuan dibuatnya website. Selain itu, gambar yang ditampilkan juga terkesan hasil gambar dari seorang fotografer professional. Kemudian, jika gambar-gambar tersebut di klik, maka akan ditampilkan fitur yang berisi artikel. Dalam fitur blog ini, artikel-artikel ditata rapi dengan desain layout berbentuk kotak. Artikel berisi berita tentang pencapaian apa saja yang ukm-ukm telah capai. Dengan adanya fitur blog, website menjadi lebih menarik karena tidak hanya menyediakan produk yang dijual namun

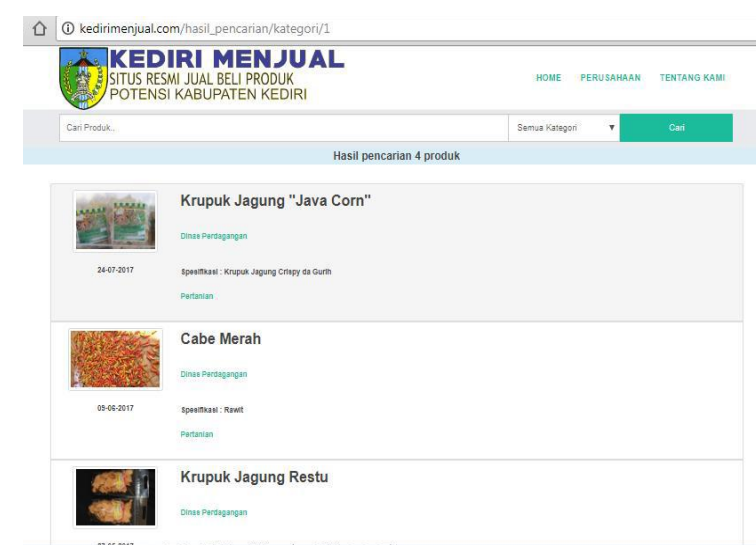

(i) website kedirimenjual.com juga terdapat berita tentang perkembangan ukm.

\section{- Komparasi Tampilan Produk}

Produk yang ditampilkan dalam suatu website merupakan produk-produk unggulan yang diharapkan dapat dipasarkan dengan jangkauan yang lebih jauh. Semakin banyak produk unggulan yang dimiliki daerah, maka konten tampilan produk dalam website juga akan beragam. Namun yang perlu dipahami bahwa gambar-gambar produk harus ditampilkan dengan cara yang menarik, supaya pengunjung tertarik untuk membeli.

Gambar 5. Komparasi Tampilan Produk 
Berdasarkan gambar 5, menunjukkan tampilan produk masingmasing website. Jika dibandingkan, dapat dikatakan bahwa tampilan produk pada website kedirimenjual.com sangat sederhana. Gambar produk juga dibuat dengan cara yang biasa, bukan menggunakan Teknik fotografi yang baik. Bahkan terkesan tidak ada pemilihan gambar yang cocok dan sesuai untuk ditampilkan di website. Selain itu, gambar-gambra produk dibuat dengan menambahkan bentuk kotak persegi panjang yang berisi nama dan spesifikasi produk saja. Jika dilihat lebih seksama, gambar produk tersebut juga tidak menjelaskan mengenai harga jual barang serta ketersediaan barang.

Pada website banyuwangimall.com, produk yang yang ditampilkan dalam gambar-gambar produk terkesan lebih mewah. Gambar dibuat dengan jelas tanpa ada background, sehingga pembaca dapat fokus pada gambar yang ditampilkan. Selain itu, gambar juga dibuat dengan Teknik fotografi dan

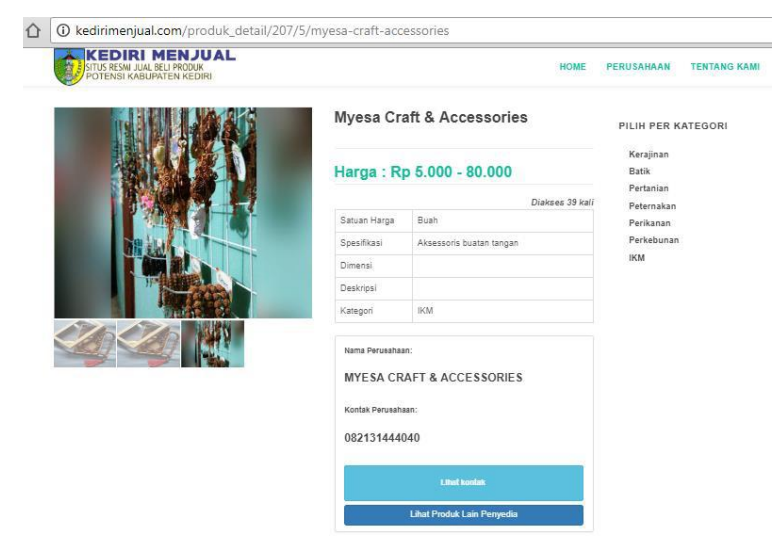

(i) website kedirimenjual.com gambar terlihat jelas. Fitur dalam website banyuwangi-mall.com lebih jelas dan berwarna, juga terdapat wishlist serta rating disetiap produk setiap itemnya. Dengan demikian, pengunjung website banyuwangi-mall.com merasa mendapat suguhan informasi dan gambar yang lebih baik jika dibandingkan dengan website kedirimenjual.com.

\section{- Komparasi Tampilan Pembelian}

Ketika berbagai informasi terkait website telah dibuat dengan baik, maka yang terpenting adalah apakah keputusan pengunjung akan melanjutkan hingga pembelian produk ataukah tidak. Jika pengunjung website menyelesaikan selancarnya hingga memutuskan untuk membeli produk dari website yang dibaca, maka tujuan pembuatan website dapat dikatakan berhasil. Salah satu hal yang berkontribusi pada keputusan pengunjung untuk membeli produk adalah adanya fitur pembelian serta informasi penting terkait pembelian tersebut.

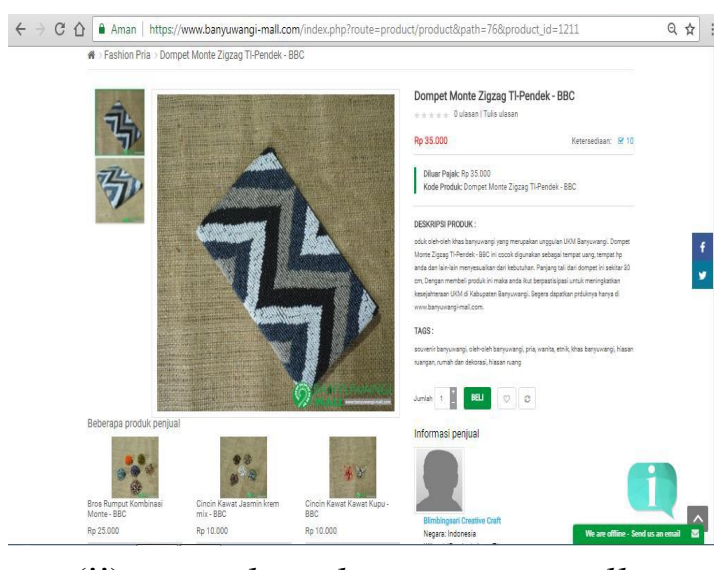

(ii) website banyuwangi-mall.com Gambar 6. Komparasi Tampilan Pembelian

Berdasarkan gambar 6 mengenai tampilan fitur pembelian, menunjukkan bahwa tampilan pembelian pada website kedirimenjual.com sudah memiliki gambar yang dapat di zoom in maupun zoom out. Artinya, pengunjung memiliki informasi mencukupi terkait keputusan untuk membeli produk yang dilihatnya. Namun demikian, dalam website kedirimenjual.com item produk yang ditampilkan belum memiliki informasi mengenai ketersediaan barang yang dapat dibeli. Selain itu, informasi harga barang masih belum jelas. Harga barang yang ditampilkan masih berupa range antara harga terendah sampai tertinggi. Jadi tidak ada kejelasan antara item dengan harga yang tertera. Informasi terkait harga juga belum ada khususnya mengenai apakah harga yang tertera 
sudah dikenai biaya ongkos kirim (ongkir), ataukah sudah dikenai pajak.

Jika dibandingkan dengan website banyuwangi-mall.com, terdapat stok item barang yang masih tersedia. Harga belum termasuk PPN maupun biaya ongkir. Terdapat berapa jumlah item barang yang ingin dibeli beserta wishlist. Deskripsi produk juga detail dan terdapat tags yang bisa membuat kategori keseluruh pencarian yang berhubungan dengan item barang tersebut. Jadi tidak hanya satu kategori saja.

\section{Re-design website kedirimenjual.com}

Berdasarkan analisis komparasi dengan website sejenis serta hasil diskusi dengan pengelola website Dinas Perdagangan Kabupaten Kediri, maka diperlukan perbaikan mendasar pada website kedirimenjual.com. perbaikan yang dimaksud meliputi tampilan website yang tidak informatif, fitur yang tidak lengkap, tampilan produk yang belum dibuat secara profesional, hingga informasi terkait produk dan pembelian produk. Berkaitan dengan hal tersbut, tim pengabdian kemudian melakukan redesign pada website kedirimenjual.com. Tahapan yang dilakukan adalah mengumpulkan database produk unggulan Kabupaten Kediri yang memerlukan promosi melalui website, pengambilan gambar secara professional, menambahkan informasi terkait produk dari masing-masing pelaku usaha, serta me-layout fitur website. Hasil dari redesign ini ditampilkan sebagai berikut:

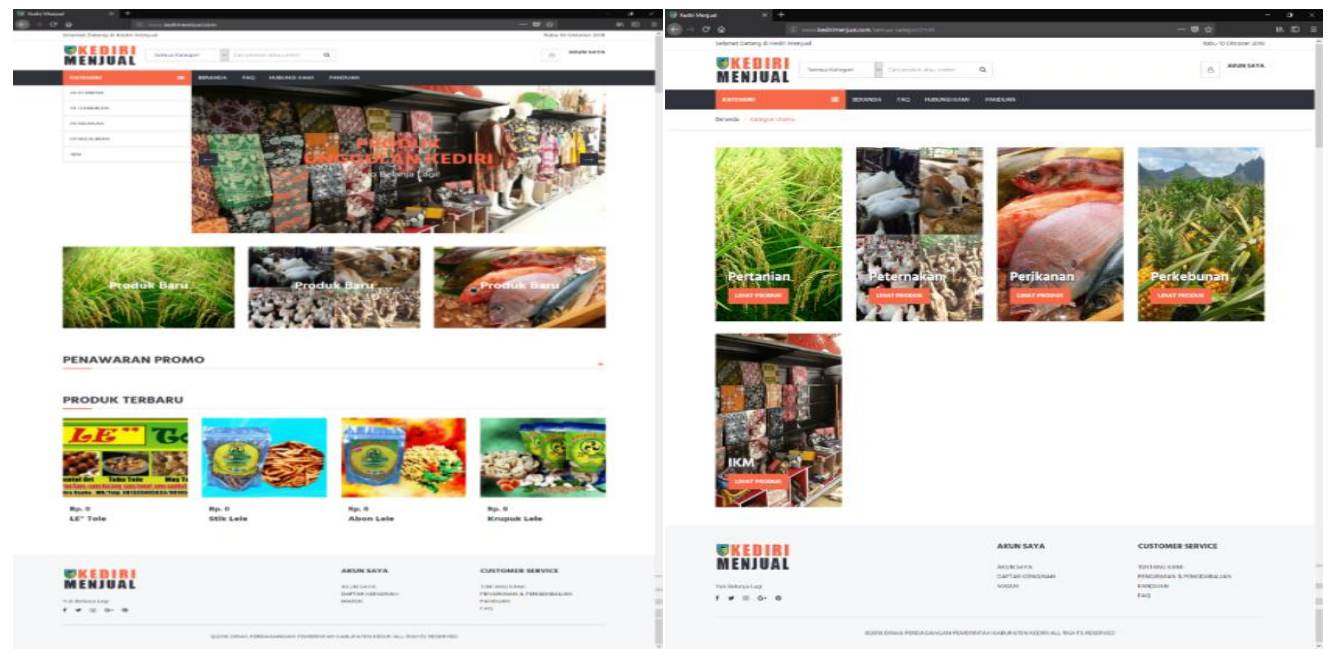

Gambar 7. Halaman Homepage Kedirimenjual.com

Berdasarkan gambar 7, terlihat tampilan website kedirimenjual.com setelah dilakukan perubahan tampilan. Berdasarkan gambar tersebut, kondisi website kedirimenjual.com lebih menarik dibandingkan dengan tampilan sebelumnya. Fitur yang ada di website juga telah dibuat lebih informatif disesuaikan dengan tujuan pembuatan website yakni mengenalkan produk, memasarkan produk dan menjual produk lebih jauh. Gambar produk yang ditampilkan dalam website kedirimenjual.com juga terkesan lebih jelas, tajam dan fokus pada produk. 


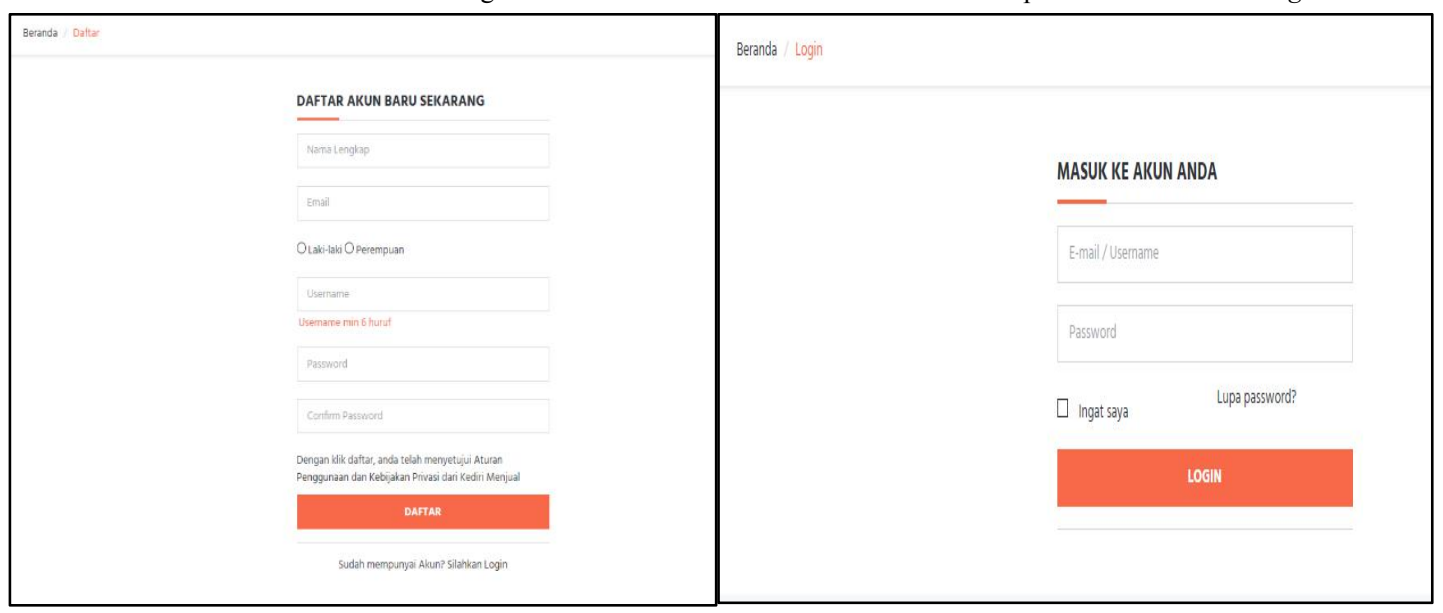

Gambar 8. Halaman Daftar Akun Kedirimenjual.com

Perubahan lain yang dibuat dalam website kedirimenjual.com adalah menambahkan fitur "Daftar Akun". Fitur tersebut dibuat bagi pelaku usaha yang memiliki produk dan berharap produknya dapat dipasarkan dan dijual secara online. Setiap pelaku usaha di Kabupaten Kediri dilakukan pendataan berkaitan dengan informasi produk yang dihasilkan, kemudian setiap pelaku usaha tersebut diberikan kemudahan untuk mendaftarkan produknya dengan cara mendaftar melalui menu tersebut. Dengan kata lain, bagi pelaku usaha yang telah
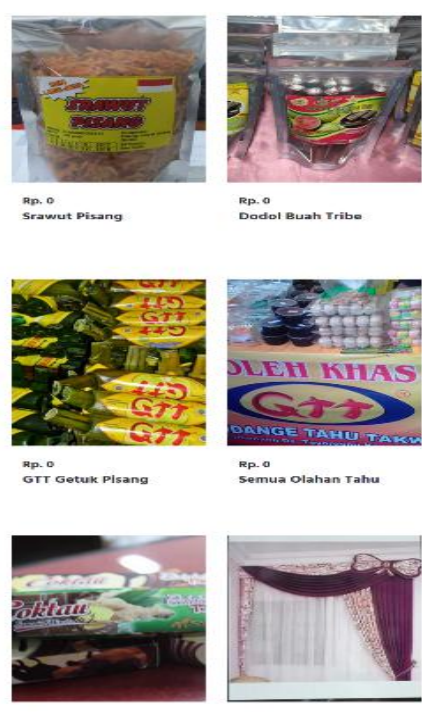

Mp.
Cokelat Tahu
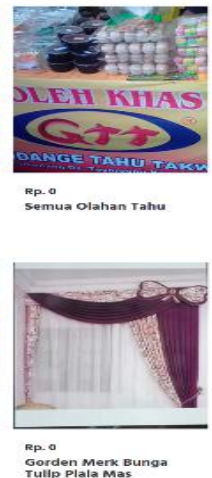

memiliki akun, dan kemudian disetujui oleh admin website kedirimenjual.com maka produknya akan secara otomatis ditampilkan di website. Jika kemudian pelaku usaha tersebut ingin mengupdate berbagai informasi terkait barang yang dijual, dapat dilakukan secara mandiri melalui akun yang telah dimiliki. Contoh bentuk tampilan barang-barang yang dijual dan di upload oleh masing-masing pelaku usaha ditunjukkan pada gambar 9 berikut:

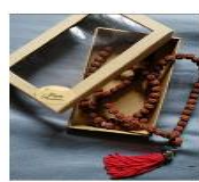

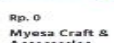
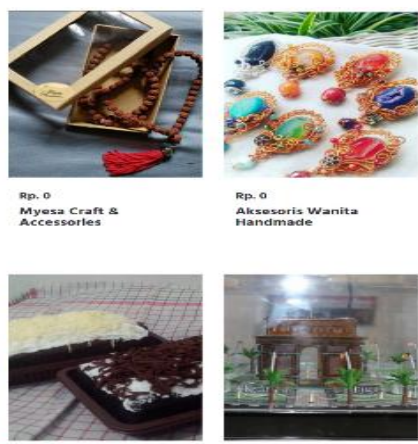

sp.o

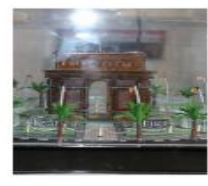

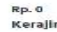

Gambar 9. Halaman Kategori Item

Jika dibandingkan dengan tampilan dan isi dalam website kedirimenjual.com sebelumnya, maka re-design website kedirimenjual.com telah memberikan perubahan yang optimal pada peningkatan brand website kedirimenjual.com. seperti yang disampaikan oleh Siswanto (2013), jika 
penggunaan social media berupa website kedirimenjual.com dapat digunakan secara optimal oleh para pelaku UMKM, maka tidak hanya produk yang akan dikenal lebih luas (Wardhana, 2015) namun juga daya saing UMKM juga akan meningkat (Ramadhani \& Arifin, 2013) serta berbiaya murah (Sanjaya \& Tarigan, 2009).

\section{SIMPULAN}

Produk UMKM di Kabupaten Kediri dengan varietas yang beragam sangat berpotensi untuk dipasarkan lebih luas. Dalam upaya memasarkan dan mengenal produk unggulan daerah, Pemerintah Kabupaten Kediri memfasilitasi pelaku usaha UMKM berupa marketplace website kedirimenjual.com. Keberadaan website tersebut dapat digunakan oleh pelaku UMKM untuk mengenal produk, memasarkan serta meningkatkan daya saing UMKM. Keberadaan website kedirimenjual.com yang telah dilakukan re-design diharapkan mampu memberikan manfaat bagi pelaku UMKM dalam mendapatkan konsumen yang berasal dari luar daerah. Berbagai manfaat lain juga diperloh pelaku UMKM melalui optimalisasi penggunaan website kedirimenjual.com antara lain meringankan biaya pemasaran, UMKM dapat terhubung dengan bisnis lain, serta memberikan nilai tambah (Suryadi, 2014). Melalui kegiatan optimalisasi website kedirimenjual.com, tampilan website, terutama untuk pengguna dan beberapa fitur website telah diperbaiki. Sistem penggunaan website kedirimenjual.com juga telah menambahkan fitur pengguna melalui pembuatan akun pendaftaran yang memungkinkan pengguna berinteraksi langsung dengan pelaku UMKM serta melakukan transaksi pembelian secara langsung dengan pihak pelaku UMKM terkait. Bagi pelaku UMKM, dalam upaya meningkatkan kualitas produk, pelaku UMKM perlu secara berkala melakukan update konten pada website.
Lebih jauh, penggunaan website oleh pelaku usaha UMKM diharapkan tidak hanya digunakan sebagai alat untuk melakukan promosi atau mencari peluang bisnis, tetapi juga harus diimbangi dengan pengelolaan administrasi yang baik. Perlu dilakukan pengembangan website dan e-commerce sebagai sarana untuk promosi dan pemasaran produkproduk usaha, sehingga akan meningkatkan volume penjualan dan meningkatkan pendapatan. Peningkatan pendapatan ini pada akhirnya akan mengembangkan usaha kecil dan menengah tersebut. Disisi lain, optimalisasi website kedirimenjual.com masih memiliki berbagai kendala yang memerlukan dukungan Pemerintah Kabupaten Kediri, kendala tersebut meliputi perlunya kebijakan yang jelas bagi pengembangan website kedirimenjual.com, penyediaan infrastruktur yang mencukupi, serta peningkatan kualitas sumber daya manusia pengelola website kedirimenjual.com.

\section{DAFTAR PUSTAKA}

Anggraeni, A. A. (2008). Manajemen Keyword: Strategi Pemasaran Online Menggunakan Search Engine. Jurnal Pendidikan Akuntansi Indonesia, 6(2), 60-69. Retrieved from

https://journal.uny.ac.id/index.php/j pakun/article/view/934/744

APJII. (2019). Survey Penetrasi dan Profil Perilaku Pengguna Internet Indonesia tahun 2019.

Jauhari, J. (2010). Upaya Pengembangan Usaha Kecil dan Menengah (UKM) dengan Memanfaatkan E-Commerce. Jurnal Sistem Informasi (JSI), 2(1), 159-168. Retrieved from https://media.neliti.com/media/publi cations/130277-ID-upayapengembangan-usaha-kecil-danmenen.pdf

Ramadhani, F., \& Arifin, Y. (2013). Optimalisasi Pemanfaatan

Teknologi Informasi Komunikasi Berbasis E-Commerce Sebagai 
Media Pemasaran Usaha Kecil

Menengah Guna Meningkatkan

Daya Saing dalam Menghadapi

Masyarakat Ekonomi Asean 2015.

Economics Development Analysis

Journal,

https://doi.org/10.15294/edaj.v2i2.1

401

Sanjaya, R., \& Tarigan, J. (2009). Creative Digital Marketing:

Teknologi Berbiaya Murah, Inovatif, dan Berdaya Hasil Gemilang. Jakarta: Elex Media Komputindo.

Siswanto, T. (2013). Optimalisasi Sosial

Media Sebagai Media Pemasaran

Usaha Kecil Menengah. Jurnal Liquidity, 2(1), 80-86.

Suryadi, I. G. I. (2014). Penggunaan Social Media dalam Aktivitas Usaha Kecil dan Menengah (UKM) di Kabupaten Badung. Soshum Jurnal Sosial Dan Humaniora, 4(3), 217227. Retrieved from http://ojs.pnb.ac.id/index.php/SOSH UM/article/download/430/364/

Wardhana, A. (2015). Strategi Digital Marketing dan Implikasinya pada Keunggulan Bersaing UKM di Indonesia. Forum Keuangan Dan Bisnis IV, 327-337. 